\title{
Status of Self-medication Among the Patients Attending Outpatient Department in Selected Private Hospitals in Dhaka City
}

\author{
Hasan $\mathrm{R}^{1^{*}}$, Yasmin $\mathrm{N}^{2}$, Seoty $\mathrm{NR}^{2}$, Hasan $\mathrm{MM}^{3}$, Shahjahan $\mathrm{M}^{2}$ \\ ${ }^{1}$ Samorita Hospital Ltd., Dhaka, Bangladesh; ${ }^{2}$ Department of Public Health, State University of \\ Bangladesh; ${ }^{3} 250$ Bedded TB Hospital, Shyamoli, Dhaka, Bangladesh.
}

\begin{abstract}
Background: Self medication is a common practice in developing countries. Inappropriate self-medication causes wastage of resources, increases resistance of pathogens and generally causes grave health hazards such as drug reactions, perpetuated suffering and dependence on drugs.
\end{abstract}

Objectives: The purposes of this study were to determine the status of self-medication, types of medicine used and reasons of self medication.

Methods: It was a cross sectional study and the study extended from November 2017 to March 2018. The study was conducted purposively selected two private hospitals in Dhaka city, which had outpatient department, namely, Samorita Hospital Ltd. and Popular specialized Hospital Ltd. from each zone of Dhaka. The calculated sample size was 303 .

Results: One hundred and fifty two respondents were interviewed from each hospital. Every $3^{\text {rd }}$ patient was selected for interview according to the selection criteria. A pretested semi-structured interviewer administered questionnaire was used for collecting data. Majority of the respondents were male $(62.40 \%)$. This study reported that more than half $(68.98 \%)$ of the respondents practiced self medication for their complaints. Highest percentages of complaints for taking self medication were respiratory tract infections (27.49\%) and gastrointestinal disorders (21.51\%). Most common drugs used for self medication were $\mathrm{H}_{2}$ receptor blocker/PPI (23.98\%), antibiotics (21.35\%) and antipyretic (18.42\%). Nearly half (40.92\%) of the respondents used self medication for quick relief, one forth $(23.43 \%)$ of the respondents for previous experience, seventeen percent of the respondents took self medication due to lack of time. The commonest source of medicine was pharmacy $(74.16 \%)$.

Conclusion: Self-medication is relatively a common problem in Bangladesh. So, the existing laws must be implemented strongly to stop selling medicine by the pharmacists without prescription. Awareness should be developed about the dangers of self medication.

Keywords: Status of medication, Urban area, Outpatient, Private hospital.

\section{Introduction}

Self-medication is a worldwide problem and is common practices in developing countries. ${ }^{1}$ Selfmedication can be defined as taking of drugs, herbs or home remedies on one's own initiative, or on the advice of another person, without consulting a doctor. $^{2}$ Inappropriate self-medication causes wastage of resources, increases resistance of pathogens and generally causes grave health hazards such as drug reactions, perpetuated suffering and dependence on drugs. Several factors could affect the self medication practice and that includes sex, age, race, scholastic and economic status. ${ }^{1}$ In the United Kingdom where on the average $50 \%$ of health care takes place within the realm of self medication.

Correspondence: Dr. Md. Riyadh Hasan, Samorita Hospital Ltd., Dhaka, Bangladesh; e-mail: dr.riyadh.hasan@gmail.com; ORCID: 0000-0002-9091-5137
In neighboring countries like India, $35.48 \%$ male and $15.56 \%$ female used self -medication due to the lack of time. ${ }^{3}$ Where in Nepal, a $59 \%$ of the study population took self medication for minor illness. ${ }^{4}$ In Srilanka, prevalence of self medication use in urban and rural population was $33.9 \%$ and $35.3 \%$ respectively. ${ }^{5}$ In Bangladesh, a study was conducted on the students of selected medical colleges of Dhaka city showed almost moiety of the respondents $47.06 \%$ reported practiced selfmedication for their illness. ${ }^{6}$ While in an another study found that $26.69 \%$ people experienced self medication with antibiotics. ${ }^{7}$

The most paramount perils cognate to selfmedication practices are drug interactions, medications abuse or dependence, misdiagnosis and erroneous choice of treatment. A major issue of self medication with antimicrobials is the 
emergence of human pathogens resistance globally especially in developing countries, where antibiotics are often available without a prescription. ${ }^{8}$ There are some factors influence selfmedication like lack of time, urge of quick relief, poverty, lacking of education and awareness, ignorance, lack of health services, misbelieves, extensive advertisement and availability of drugs. In many cases people are using traditional home remedies to reduce sufferings immediately where many of them are not medically proved. ${ }^{3}$ Home remedies are simply prepared medication or tonic, made with ingredients available at home, often of unproven effectiveness administered without prescription or professional supervision and additionally kenned as totka. ${ }^{9}$ Traditions run deep in the communities of Bangladesh, even many people are reluctant to seek professional medical care. Home remedies are quite prevalent in Bangladesh and practically every household has multiple remedies for avoidance and treatment of various diseases..$^{10}$ Thus this issue of self-medication must be addressed and approached with high vigilance and clear vision. Utilisation of medicines by oneself can engender irreversible damage to health. The general people must sentinel against the hazards of infelicitous self-medication practices.

In the context of Bangladesh, it is still needed to explore this subject in getting more detail scenario of self medication.

\section{Materials and Methods}

It was a cross sectional study and the study extended from November 2017 to March 2018. The study was conducted at selected private hospitals in Dhaka city namely Samorita Hospital Ltd. and Popular specialized Hospital Ltd. which had outpatient department. Dhaka is the capital city of Bangladesh and is the principal city of Dhaka district and division. It is divided into north and south zone. One hospital from each zone was selected purposively.

The sample size was calculated by using the formula, $\mathrm{n}=\left(\mathrm{Z}^{2 *} * \mathrm{p} * \mathrm{q}\right) / \mathrm{d}{ }^{2}$ And the calculated sample size was 303. Where $\mathrm{p}=0.27(26.69 \%$ participants experienced self medication with antibiotics). ${ }^{7}$ Respondents were equally distributed. One hundred and fifty two respondents were selected from each hospital.

From each hospital 152 respondents were interviewed. Calculated sample size was 303 . The outpatient departments of the hospitals were visited by 25 patients daily. Data were collected five days in a week. Thus 1000 patients came during the study period of 8 weeks and as such given the sampling interval of 3.30 . So every $3^{\text {rd }}$ patient was selected for interview according to the selection criteria until the fulfillment of the desired sample size.

A semi structured interviewer-administered questionnaire was developed which had 2 sections. Section-I consisted of socio-demographic characteristics included age, sex, religion, marital status, education, occupation, personal and annual family income, type of the family, number of family members, number of children and housing condition and section-II consisted of factors related to self medication included presenting complaints, days of sufferings, consultation of health care professional, medicine used without consultation, type of drugs used for self medication, source of medicine, dosages of medicine, information regarding self medication, home remedies, causes of self medication, side effects of self medication, measures taken for side effects of self medication, sharing prescription and advising medicine to others. There were total 31 questions. It was pre-tested among 10 (ten) patients similar to the study population in other place. Verbal informed consent was taken from each respondent assuring that the collected data would be anonymous and kept confidential. Data were collected by researcher himself.

The Statistical Package for Social Science (SPSS) was used to analyze the data.

Approval obtained from the Ethical Review committee of the State University of Bangladesh. Permission was taken from the respective departments of selected private hospitals in Dhaka city. Respondents had right to refuse and withdraw from the study at any time was ensured.

\section{Results}

It was found that $62.40 \%$ respondents were male and $37.60 \%$ were female. The mean age of the respondents was $34.90 \pm 11.98$ years, minimum 18 years and maximum 80 years. In the same table, educational status of the respondents shows that majority $36.96 \%$ completed SSC education followed by graduate $36.30 \%$. Again out of 303 respondents $36.60 \%$ were in non government service, $20.79 \%$ were students, $13.86 \%$ house wives, $11.22 \%$ were in business, $6.93 \%$ government service holder and $10.89 \%$ others (included daily wage earner, house maid, retired, freelancer, farmer and unemployed). Here the mean annual family income of the respondents was $8,73,537.95 \pm 5,22,997.47 \mathrm{BDT}$, minimum 50,000 BDT and maximum 28,00,000 BDT (table I). 
Table I: Distribution of the respondents by sex, age, education, occupation and annual family income. $(\mathrm{n}=303)$

\begin{tabular}{|c|c|c|}
\hline Sex & No of respondents & $\%$ \\
\hline Male & 189 & 62.40 \\
\hline Female & 114 & 37.60 \\
\hline Total & 303 & 100 \\
\hline Age group & No of respondents & $\%$ \\
\hline$\leq 30$ years & 128 & 42.20 \\
\hline $31-45$ years & 118 & 38.90 \\
\hline $46-55$ years & 39 & 12.90 \\
\hline $56-70$ years & 16 & 5.30 \\
\hline$\geq 71$ years & 2 & 0.70 \\
\hline Total & 303 & 100 \\
\hline \multicolumn{3}{|c|}{ Mean age $=34.90 \pm 11.98$ years, Minimum $=18$ years, Maximum $=80$ years } \\
\hline Educational level & No of respondents & $\%$ \\
\hline Illiterate & 12 & 3.96 \\
\hline Primary education & 29 & 9.57 \\
\hline SSC & 112 & 36.96 \\
\hline Graduate & 110 & 36.30 \\
\hline Post graduate & 40 & 13.20 \\
\hline Total & 303 & 100 \\
\hline Occupation & No of respondents & $\%$ \\
\hline Government service & 21 & 6.93 \\
\hline Non government service & 110 & 36.31 \\
\hline Business & 34 & 11.22 \\
\hline Student & 63 & 20.79 \\
\hline House wife & 42 & 13.86 \\
\hline Others & 33 & 10.89 \\
\hline Total & 303 & 100 \\
\hline Annual family income & No of respondents & $\%$ \\
\hline$\leq 5,00,000 \mathrm{BDT}$ & 87 & 28.71 \\
\hline $5,00,001-10,00,000 \mathrm{BDT}$ & 118 & 38.94 \\
\hline $10,00,001-15,00,000 \mathrm{BDT}$ & 71 & 23.43 \\
\hline $15,00,001-20,00,000$ BDT & 18 & 5.94 \\
\hline$\geq 20,00,001 \mathrm{BDT}$ & 9 & 2.97 \\
\hline Total & $\mathbf{3 0 3}$ & 100 \\
\hline Mean $=873537.95 \pm 522997$ & $=28,00,000$ & \\
\hline
\end{tabular}

More than half $(68.98 \%)$ respondents took medicine without asking any professional and $31.02 \%$ respondents did not (figure 1 ).

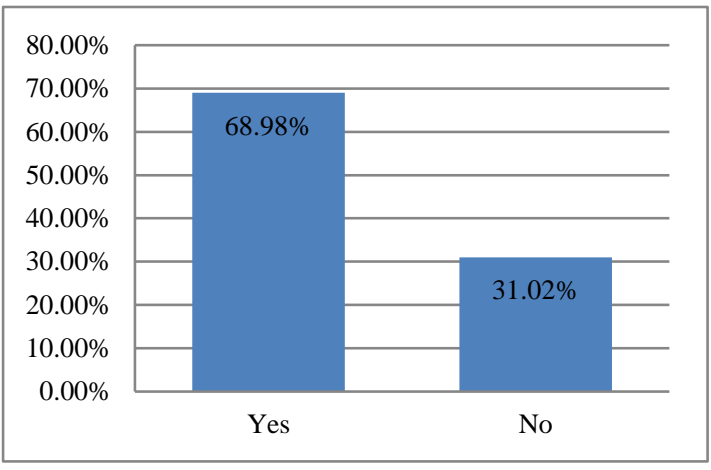

Figure 1: Distribution of the respondents by using self medication. $(\mathrm{n}=303)$

About $40.92 \%$ respondents took self medication for quick relief, $23.43 \%$ respondents used self medication from previous experience, $17.82 \%$ respondents took self medication due to lack of time and $14.85 \%$ self medicated due to high consultation fee of the consultants, $1.98 \%$ for financial crisis and $0.99 \%$ others (included believed in home remedies and parental advice) (figure 2).

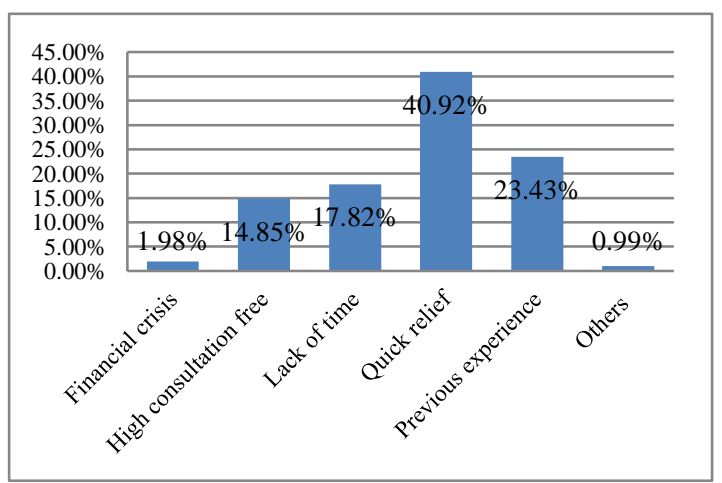

Figure 2: Distribution of the respondents by reasons of self medication. $(n=303)$ 
Generally, there were some clinical conditions for which respondents used self-medication like respiratory tract infections (includes sore throat, cough, running nose, shortness of breath, Haemoptysis) $27.49 \%, 21.51 \%$ complained of gastrointestinal disorders (includes abdominal pain, vomiting, loose motion, constipation, nausea, loss of appetite), $18.18 \%$ came with fever, $12.20 \%$ headache, $9.98 \%$ came with skin and soft tissue infection, 9.53\% respondents suffered from musculoskeletal disorders (includes ankle sprain, knee pain, back pain, spinal pain, ankle swelling and pain) and $1.11 \%$ respondents came with kidney and urinary tract disorders (includes burning micturation, urinary retention). About $59.41 \%$ respondents of total 303 advised medicine to others and $40.59 \%$ respondents did not. A highest majority $96.37 \%$ of 303 respondents never shares prescription to others but only $3.63 \%$ respondent's shared prescription to others.

Table II: Distribution of the respondents by presenting complaints, advising medicine and sharing prescription to others and necessity of consultation for minor complaints. $(n=303)$

\begin{tabular}{lcc}
\hline Complaints & $\begin{array}{c}\text { No of } \\
\text { respondent } \\
\text { s }\end{array}$ & \% \\
\hline Headache & 55 & 12.2 \\
Respiratory tract infections & 124 & 27.4 \\
Musculoskeletal disorders & 43 & 9.53 \\
Gastrointestinal disorders & 97 & 21.5 \\
Fever & 82 & 18.1 \\
Skin and soft tissue infection & 45 & 8 \\
$\begin{array}{l}\text { Kidney and urinary tract } \\
\text { disorders }\end{array}$ & 5 & 1.98 \\
& & \\
\hline
\end{tabular}

\begin{tabular}{|c|c|c|}
\hline Advising medicine & $\begin{array}{c}\text { No of } \\
\text { respondent } \\
\text { s }\end{array}$ & $\%$ \\
\hline Yes & 180 & $\begin{array}{c}59.4 \\
1\end{array}$ \\
\hline No & 123 & $\begin{array}{c}40.5 \\
9\end{array}$ \\
\hline Total & 303 & 100 \\
\hline Sharing prescription & $\begin{array}{c}\text { No of } \\
\text { respondent } \\
\text { s }\end{array}$ & $\%$ \\
\hline Never & 292 & $\begin{array}{c}96.3 \\
7\end{array}$ \\
\hline Sometimes & 11 & 3.63 \\
\hline Total & 303 & 100 \\
\hline Necessity of consultation & $\begin{array}{c}\text { No of } \\
\text { respondent } \\
\text { s } \\
\end{array}$ & $\%$ \\
\hline Yes & 48 & $\begin{array}{c}15.8 \\
4\end{array}$ \\
\hline No & 255 & $\begin{array}{c}84.1 \\
6\end{array}$ \\
\hline Total & 303 & 100 \\
\hline
\end{tabular}

Again $84.16 \%$ respondents thought they need not any consultation of doctor for minor complaints whereas only $15.84 \%$ respondents said they need doctors' consultation for minor complaints. Among the respondents who used different types of drugs as selfmedication, $23.98 \%$ took $\mathrm{H}_{2}$ receptor blocker/PPI as self-medication, $21.35 \%$ took antibiotics, $18.42 \%$ used antipyretic, $13.45 \%$ anti-histamines, $11.11 \%$ anti-inflammatory/analgesic, $3.22 \%$ anti-emetics, $7.58 \%$ others (included anti spasmodic, Prochlorperazine, laxatives, oral gel, sedative, ointments, nasal drop, vitamins, anti septic solution, syrup) and $0.88 \%$ could not mention the name of the medicine. Respondents got information about dosages of medicine from different ways. More than half $(58.37 \%)$ respondents got information about the dosages of medicine from pharmacist, next $25.36 \%$ from family members/friends, $15.31 \%$ respondents got information from previous experiences and $0.48 \%$ had no idea about dosages of medicine. Most of the respondents $(74.16 \%)$ got their medicine from pharmacy while $25.84 \%$ from house hold (table III).

Table III: Distribution of the respondents by using drugs, getting information about the dosages of medicine and source of medicine. $(n=209)$

\begin{tabular}{|c|c|c|}
\hline Type of drugs & $\begin{array}{c}\begin{array}{c}\text { No of } \\
\text { respondents }\end{array} \\
\end{array}$ & $\%$ \\
\hline Antibiotics & 73 & 21.35 \\
\hline Antipyretic & 63 & 18.42 \\
\hline Anti-inflammatory/Analgesic & 38 & 11.11 \\
\hline Anti-emetics & 11 & 3.22 \\
\hline Anti-histamines & 46 & 13.45 \\
\hline $\mathrm{H}_{2}$ receptor blocker/PPI & 82 & 23.98 \\
\hline Others & 26 & 7.58 \\
\hline Could not mention the name & 3 & 0.88 \\
\hline \multicolumn{3}{|c|}{ Multiple responses } \\
\hline Getting information & $\begin{array}{c}\begin{array}{c}\text { No of } \\
\text { respondents }\end{array} \\
\end{array}$ & $\%$ \\
\hline By consulting pharmacist & 122 & 58.37 \\
\hline $\begin{array}{l}\text { By consulting family } \\
\text { members/friends }\end{array}$ & 53 & 25.36 \\
\hline Previous experience & 32 & 15.31 \\
\hline No idea about dosages & 1 & 0.48 \\
\hline $\begin{array}{l}\text { Own knowledge (Pharmacy } \\
\text { student) }\end{array}$ & 1 & 0.48 \\
\hline Total & 209 & 100 \\
\hline Source & $\begin{array}{c}\begin{array}{c}\text { No of } \\
\text { respondents }\end{array} \\
\end{array}$ & $\%$ \\
\hline Pharmacy & 155 & 74.16 \\
\hline Household & 54 & 25.84 \\
\hline Total & 209 & 100 \\
\hline
\end{tabular}


There was statistically significant association $(p \leq 001)$ between self medication and necessary of taking consultation from doctor for minor complaints. More than half of the respondents said that consultation of doctors for minor complaints was not necessary. It is documented in this study that there is statistically significant association between educational level and self medication $(p \leq 0.05)$. But there was no statically significant association between the family income of the respondents and self medication $(p=0.06)$ (table IV).

Table IV: Association between socio demographic characteristics of the respondents and self medication, home remedies and necessity of consultation for minor complaints. $(n=303)$

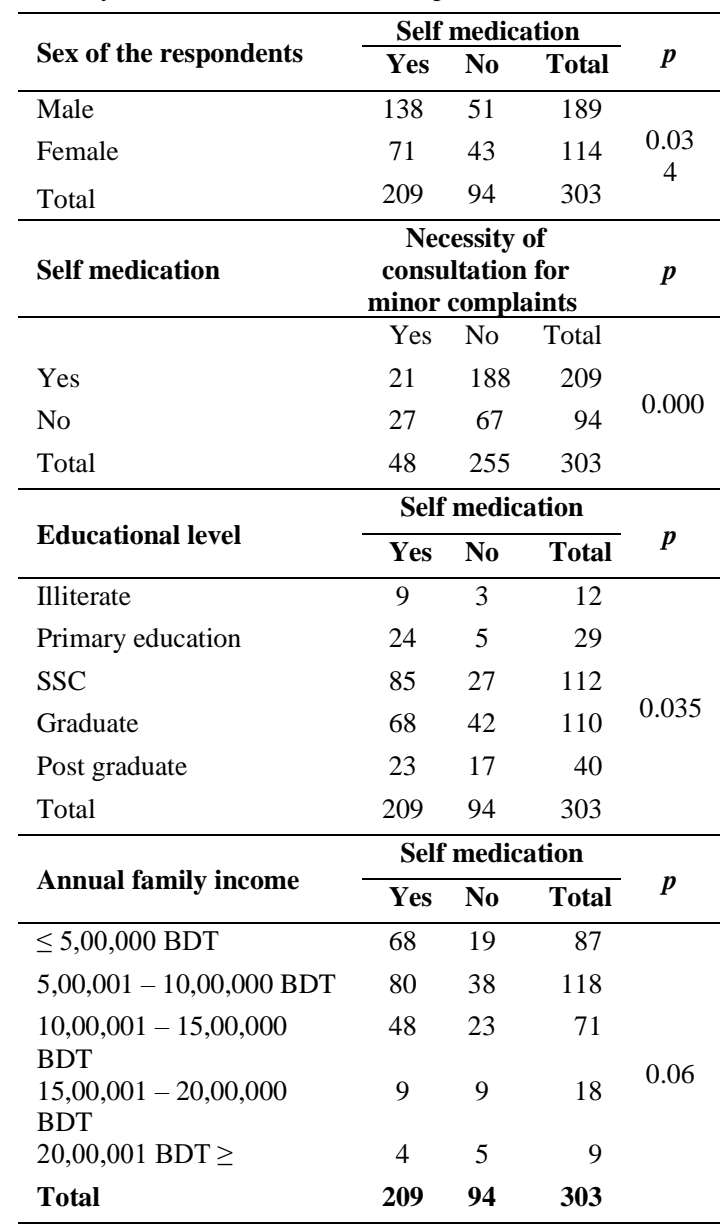

\section{Discussion}

Self-medication is an alarming practice. It would be safe, if the people who are taking it, have sufficient knowledge about its dose, time of intake, side-effects of over dose. But due to lack of information it can cause serious effects such as antibiotic resistance, hypersensitivity and allergy. This cross sectional study was conducted among 303 respondents attending the outpatient department of selected private hospitals in Dhaka city to determine the proportion of self medication among them. In this study, more than half $(68.98 \%)$ of the respondents took self medication for their complaints. The study result revealed that male respondents took more medicine without consultation of doctor for their complaints than female. There was statistically significant association between sex of the respondents and medicine used without consultation $(p \leq 0.05)$.

Higher percentage of the complaints of taking self medication were respiratory tract infections $27.49 \%$ and gastrointestinal disorders $21.51 \%$ documented in the study and both of the categories were collectively more than fifty percent. The results also showed that the most common drugs respondents used for self medication were $\mathrm{H}_{2}$ receptor blocker/PPI 23.98\%, antibiotics $21.35 \%$ and antipyretic $18.42 \% . \mathrm{H}_{2}$ receptor blocker/PPI drugs are using in our country invariably as self medication as because of lack of knowledge about drugs, misbelieve of the safety of using these drugs and availability. In this study, $21.35 \%$ respondents used antibiotics as self medication which was alarming. A study which was conducted in Rajshahi city in Bangladesh showed $26.69 \%$ participants experienced self medication with antibiotics. ${ }^{7}$ In another study in Iran, more than $53.0 \%$ of the respondents practiced self-medication with antibiotic within 3 months afore the study. ${ }^{11}$ Proximately half (40.92\%) of the respondents use self medication for quick relief and fifteen percent of the respondents took medicine of their own for the lack of time. Thus the respondents use self medication for quick relief which was kindred to the study conducted in India where $55.0 \%$ took drugs of their own for quick relief, $58.0 \%$ for lack of time. ${ }^{12}$ Other study showed homogeneous attributes like more than a moiety of self-medicated respondents $52.0 \%$ reported that they did so because they did not have time to visit formal health care facilities. ${ }^{13}$ The study results showed that the most common source of medicine was pharmacy $(74.16 \%)$ for self medication. Respondents got their medicine from pharmacies easily without any prescription where the regulatory entities were relaxed about to enforce the subsisting laws to stop selling medicine without doctors' prescription. The study findings are similar to a study conducted at Tabuk city in Kingdom of Saudi Arabia where the common source of self medication was the private pharmacy (including pharmacists), which reported by $(63.8 \%){ }^{1}$ There is homogeneous attribute of getting medicine from pharmacies for self medication in a study conducted in Riyadh, Saudi Arabia. The study showed over the counter drugs purchased from private pharmacies was the most commonly used source of self medication, reported by the majority of self medicated patients $(79.1 \%) .{ }^{13}$ 
It was found that more than a moiety (58.37\%) respondent got information about the dosages of medicine from pharmacist. Education of the respondents is considered as the most important factor in determining the utilization of self medication. There was statistically significant association between educational level and self medication $(p \leq 0.05)$. The result was consistent with a study conducted in Nigeria where there was a positive correlation between the education level of the respondents and the tendency to obtain medications from the hospital/ pharmacies. $^{14}$

\section{Conclusion}

People were getting medicine from pharmacies without prescription, so that existing laws should be implemented strongly to stop selling medicine by the pharmacist without prescription of physician. Furthermore, awareness should be developed about the dangers of sharing prescription to others, inappropriate and irrational use of medicine and its adverse effects by using appropriate communication tool.

\section{References}

1. Albalawi AH, AlAnazi BD, Althmali KA, Alzhahrani OM, Aloqbi HS. A descriptive study of self-medication practices among patients in a public health care system in Tabuk City. International Journal of Academic Scientific Research.2015;3: 127-33.

2. Bennadi D. Self-medication: A current challenge. Journal of Basic and Clinical pharmacy. 2014;1:1923. DOI: 10.4103/0976-0105.128253.

3. Jain S, Malviz R, Purviya JK. Concept of Self Medication: A Review. International Journal of Pharmaceutical \& Biological Archives.2011; 2:831-36.

4. Shankar PR, Parthal P and Shenoy N. Selfmedication and non-doctor prescription practices in Pokhara valley, Western Nepal: a questionnairebased study. BMC Family Practice. 2002, 3; I7. DOI: $10.1186 / 1471-2296-3-17$.

5. Wijesinghe PR, Jayakody RL, Seneviratne RA. Prevalence and predictors of self-medication in a selected urban and rural district of Sri Lanka: WHO South-East Asia Journal of Public Health 2012; $1: 28-41$.

6. Mosaddekll ASM, Haque M, Islam MZ, Sharmin ZR, Sharmin R, Rahman MF, Hussain DAS. practice of self-medication among students of a selected medical college of dhaka city, bangladesh. international medical journal. 2017; 24: 225-29.

7. Biswasl M, Roy MN, Manik MIN, Hossain MS, Tapu SMTA, Moniruzzaman M and Sultana S. Self medicated antibiotics in Bangladesh: a crosssectional health survey conducted in the Rajshahi City. BMC Public Health. 2014, 14:847. DOI 10.1186/1471-2458-14-847.

8. Ala C, Oguejiufar NC, Ala NC. Self Medication and its Pattern among Patients Attending the General Outpatient Clinic of a Tertiary Institution in Abakaliki, Elmnyi State, Nigeria. HSOA journal of Community Medicine and Public Health Care. 2015; $2: 8$ DOI: 10.24966/CMPH-1978/100008.

9. Merriam-Webster. home remedy. url: merriamwebster.com/dictionary/home\%20remedy\#med ical Dictionary.

10. Mahmud MR, Parvin A, Anny IP, Akter F, Tarannom SR, Moury SI, Joy SK, Akter S, Yeasmin S. home remedies of village people in six villages of dinajpur and rangpur districts, bangladesh. world journal of pharmacy and pharmaceutical sciences. 2015; 4: 63-73.

11. Sarahroodi S, Arzi Q A. Self Medication with Antibiotics, Is it a Problem among Iranian College Students in Tehran? Journal of Biological Sciences.2009; 9: 829-32.

12. Sankdia RK, Agrawal M, Rekha PB, Kothari N. A Questionnaire Based Study Regarding the Knowledge, Attitude and Practice of Self-Medication Among Second Year Undergraduate Medical Students. Int J Pharmacol and Clin Sci.2017;6:01-05. DOI: $10.5530 /$ ijpcs.6.1.1

13. S.A. Alghanim. Self-medication practice among patients in a public health care system. EMHJ. 2011;17:409-16.

14. Afolabi AO. Factors influencing the pattern of selfmedication in an adult Nigerian population. Annals of African Medicine. 2000; 7: 120-27. 